Informatika i sistemy upravleniya. - 2017. - No. 3(53). - P. 67-74.

Voronin V.V. (004183@pnu.edu.ru)

Pacific state university

\title{
MAINTENANCE SYSTEM IN CONCEPTUAL MODEL OF A TECHNICAL OBJECT
}

The article proposes the criterion for evaluating the effectiveness of the maintenance system. The basic parameters of changing the criteria, defined in the article, are negativity, acceptability, optimality and redundancy. We have devised a fragment of a conceptual diagnostic model structure in maintenance system. The analysis plays a great role in determining the possibility of providing information about the maintenance system with platform structures 1C: Enterprise.

Keywords: maintenance system, reliability, diagnosing, expert system, information support.

DOI: $10.22250 /$ isu.2017.53.67-74

For citation:

Voronin V.V. MAINTENANCE SYSTEM IN CONCEPTUAL MODEL OF A TECHNICAL OBJECT // Informatika i sistemy upravleniya. - 2017. - No. 3(53). - P. 67-74. 